\author{
DAWID LIPIŃSKI \\ Uniwersytet Mikołaja Kopernika \\ Katedra Filologii Klasycznej
}

\title{
Pole semantyczne choroby w De civitate Dei Augustyna z Hippony
}

Słowa klucze: Augustyn z Hippony, De civitate Dei, pola semantyczne, określenia choroby, określenia leczenia, język łaciński

W 410 roku na tereny prowincji Afryki dotarła wiadomość, że Rzym, oblegany przez armię gocką pod wodzą Alaryka, został zdobyty. Informacja ta stanowiła wstrząs dla całego ówczesnego świata, zarówno pogańskiego, jak i chrześcijańskiego, również dla św. Augustyna, biskupa Hippony. Rzym co prawda nie był już wtedy siedzibą cesarza (od 402 r. miastem rezydencjalnym cesarzy zachodniorzymskich była Rawenna), nadal jednak pozostawał kulturowym i towarzyskim centrum Imperium. W obliczu tej tragedii ludzie zaczęli się zastanawiać, jak mogło dojść do takiej sytuacji. Inteligencja pogańska, zwłaszcza ta, która uciekła przed Gotami z Italii do Afryki, dostrzegła w tym wydarzeniu karę bogów za odrzucenie religii przodków i postępującą chrystianizację. Augustyn zatem stanął przed realnym zagrożeniem reakcji pogańskiej nie tylko na terenach swojego biskupstwa, ale i w całej Afryce Prokonsularnej (Brown 1993: 290-292). W odpowiedzi na nie ${ }^{1}$

${ }^{1} \mathrm{Z}$ tego zagrożenia zdawał sobie również sprawę Marcelin, pełnomocnik cesarza Honoriusza do rozwiązania konfliktu z donatystami. On to był głównym pomysłodawcą tekstów Augustyna przeciwko religii pogańskiej. Augustyn przed stworzeniem De civitate Dei napisał dwa listy, jeden do Marcelina, drugi zaś do młodego poganina, Woluzjana, 
stworzył bodaj największe swoje dzieło, traktat apologetyczny De civitate $D e i^{2}$.

Zasadniczym celem tego dzieła, oprócz rozprawy z religią pogańską, stało się przedstawienie dwóch państw: niebieskiego, należącego do Boga, i ziemskiego, którym rządzi szatan. Ta podwójna celowość De civitate Dei zdeterminowała jego kompozycję, dzieląc je na dwie części: negatywną albo apologetyczną ${ }^{3}$ (księgi I-X), gdzie Augustyn starał się podważyć istotę politeizmu i zdyskredytować bóstwa pogańskie, oraz pozytywną (księgi XI-XXII), w której została przedstawiona koncepcja wspomnianych dwóch państw (Kornatowski 1977: 26-28). Kolejność tych części świadczy o tym, że biskup Hippony gruntownie przemyślał kompozycję swojego dzieła. Zanim bowiem przeszedł do wyjaśnienia idei państwa bożego, już w pierwszej części wyraźnie zarysował, kto do tego państwa będzie należał, a kto nie. W civitas Dei widział zatem zapewne siebie, czyli piewcę i obrońcę owego państwa, a także wszystkich chrześcijan. Po drugiej stronie, a więc w państwie ziemskim, musieli znajdować się poganie, zwłaszcza ci oskarżający chrześcijan o nieszczęścia, które dotknęły Rzymian. Augustyn dzielił ich na dwie grupy: imperiti, czyli prosty niewykształcony lud, oraz docti, quos impietas uesana possedit (D.c.D., VI pr. $)^{4}$. W swojej walce z religią pogańską posługiwał się on zatem w pierwszej kolejności opozycją „my - chrześcijanie" i „oni - poganie".

którego chciał nawrócić (por. Eckmann 1987). Marcelin uznał jednak, że listy te są niewystarczające do zażegnania zagrożenia reakcją pogańską, stąd powstanie późniejszego traktatu apologetycznego. Augustyn sam wspominał o tym we wstępie do księgi I swojego dzieła: „Przechwalebnego państwa Bożego bronić postanowiłem [...], najdroższy synu Marcelinie, w tym dziele, którego się domagałeś, a które stosowanie do mej obietnicy słusznie ci się należy” (D.c.D., I pr., tłum. W. Kornatowski).

2 Traktat De civitate Dei liczył ostatecznie 22 księgi. Augustyn zaczął go pisać w 412 roku, a już po pięciu latach miał gotowych dziesięć ksiąg, całość zaś ukończył w 427 roku.

3 Apologia to wygłoszona lub napisana mowa, zawierająca obronę przed zarzutami i jawną lub ukrytą pochwałę jakiejś osoby, idei, instytucji itp. Klasycznym przykładem apologii jest Obrona Sokratesa Platona; apologie były stosowane zarówno w piśmiennictwie pogańskim (głównie jako mowy genus iudiciale), jak i chrześcijańskim, zwłaszcza od II w. po Chr.

${ }^{4}$ Należy zwrócić uwagę, że do tej grupy nie zaliczał Augustyn inteligencji pogańskiej, która była przychylna poganom, czyli np. Woluzjana czy Marcelina. Do nich to bowiem autor kierował swoje dzieło i ich to, jako docti, quos impietas uesana non possedit, zamierzał nawrócić na chrześcijaństwo. 
Pierwszym zabiegiem językowym, który miał służyć budowie powyższej opozycji, było wyróżnienie grupy „nas”, czyli chrześcijan, za pomoca zaimka osobowego nos oraz zaakcentowanie światopoglądu tej grupy poprzez dodanie zaimka dzierżawczego noster. W sumie oba zaimki występują w dziesięciu pierwszych księgach 298 razy. Aby chociaż częściowo pokazać, czy jest to dużo, czy mało, warto tę liczbę odnieść do liczby paragrafów, których w dziesięciu pierwszych księgach było 285 . Łatwo zatem zauważyć, że średnio w jednym paragrafie pojawiał się jeden zaimek. Jeżeli zwrócimy uwagę, że w każdym paragrafie Augustyn rozprawiał się bądź to z jakimś pojedynczym poglądem pogańskim, bądź to przedstawiał własne stanowisko, wówczas łatwo będzie można zauważyć, że przy każdej myśli pogańskiej moglibyśmy znaleźć sformułowanie „naszego” zdania lub zaakcentowanie „nas” jako grupy opozycyjnej. Warto tu jeszcze zwrócić uwagę na to, że biskup Hippony nie używał prawie żadnych innych wyrażeń referencjalnych wskazujących na chrześcijan poza tymi zaimkami. Może to świadczyć m.in. o tym, że traktował on chrześcijan jako grupę w pełni ukonstytuowaną, której granice były wyraźnie określone. Zresztą głównymi adresatami dzieła byli przede wszystkim wyznawcy Chrystusa oraz poganie, którzy byli im przychylni, stąd brak konieczności określania chrześcijan jako grupy dobrze znanej adresatom. Grupą, która potrzebowała dokładnego określenia, byli natomiast poganie, czyli „inni”.

W celu zbudowania wizerunku pogan Augustyn posługiwał się wyrażeniami z sześciu różnych pól semantycznych: epistemicznego (np. veritas, errores, imperiti, falsi), kwantytatywnego (unus, multi, turba), moralnego (humiles, superbi, eversio probitatis, impii, impietas), verba dicendi (adversus Deum mururare), civitas (custos, rector, idonei cives, inimici) oraz choroby (morbus, medicus, medicina) ${ }^{5}$. W niniejszym artykule pokrótce przedstawię pierwszych pięć pól, bardziej szczegółowo zajmę się natomiast polem se-

${ }^{5}$ Ze względu na to, że w swojej pracy nie analizuję poszczególnych pól semantycznych całego języka łacińskiego ani też słownictwa stosowanego przez Augustyna, tylko określone słownictwo, które jest podporządkowane konkretnemu zabiegowi językowemu biskupa z Hippony, jakim jest budowa opozycji „my - chrześcijanie” - „oni - poganie", pola te są, zgodnie z podziałem Porziga, syntaktyczne, a więc niejednolite pod względem części mowy. Warto tu również zwrócić uwagę, że dla języka łacińskiego nie było do tej pory prowadzonych żadnych badań w ujęciu teorii pól semantycznych. Więcej na temat różnych koncepcji pól semantycznych por. W. Pisarek 1967 i D. Buttler 1967. 
mantycznym choroby, które, podobnie jak pole civitas, biskup Hippony stosował w metaforycznym przedstawieniu religii pogańskiej.

Bodaj najbardziej rozbudowanym i kluczowym dla Augustyna polem semantycznym, które zawiera określenia religii pogańskiej, jest pole epistemiczne. Tworzą je słowa związane $\mathrm{z}$ niewiedzą i nieprawdziwością. $\mathrm{Za}$ pomocą wyrażeń $\mathrm{z}$ tego pola poganie byli zatem określani jako ci, którzy nie posiedli całkowitej wiedzy, pełnego poznania, stąd Augustyn określał ich mianem imperiti 'ludzi nieposiadających i niechcących posiąść wiedzy' (VI pr.) oraz tenebrosi animi, czyli dusz nieoświeconych, pozostających w mroku (VII pr.). Tymi określeniami biskup Hippony wyraźnie zaznaczył, że nie posiedli oni wiedzy, którą może dać im tylko Duch Święty, dlatego są pogrążeni w mroku. Tym samym zbudował domyślny wizerunek chrześcijan jako tych, którzy dostąpili Bożego oświecenia. Określił religię pogańskąjako veteres opiniones 'dawne mniemania' (VII $p r$.), godząc przy tym w wiarygodność mos maiorum, czyli obyczaju przodków. Inne określenie dla religii pogańskiej z tego pola semantycznego to gloria vanitatis "pochwała głupoty, cześć dla fałszu' (VI pr.). Niesie ono w sobie silny ładunek wartościujący poprzez ironiczne zestawienie dwóch słów o takim znaczeniu. W opozycji do niego znajduje się określenie chrześcijaństwa mianem vires veritatis, siłą prawdy' (VI pr.) bądź samą veritas 'prawdą' (VII pr.).

Bezpośredni związek z tym polem ma pole semantyczne kwantytatywne, które razem z określeniami fałszu było podstawą kreowania wizerunku Boga chrześcijańskiego i stojących w opozycji do Niego bóstw pogańskich. Ten pierwszy jest nazywany Deus verus et unus 'Bóg prawdziwy i jedyny' (VI pr.), bóstwa pogańskie zaś są określane mianem falsi 'fałszywych' i mul$t i$ 'licznych' (VI pr.). Na określenie ich mnogości Augustyn używa jeszcze określenia turba (V pr.), które jest zdecydowanie bardziej nacechowane pejoratywnie niż neutralne multi. Oznacza ono bowiem nie tylko wielość, lecz także podkreśla jego bezład i nieuporządkowanie: „Alii nummos numerabant, ab aliis tabellae obsignabantur; domus erat non meretricio conventu sed praetoria turba referta" (Cic., Verr., II 1, 137).

Następnym polem semantycznym, z którego biskup Hippony czerpie określenia, jest pole moralne. Pogan dla przykładu określał jako superbi 'ludzie pyszni, zarozumiali, odznaczający się pewną butą' (I pr.), iniusti 'niesprawiedliwi' (I 8) czy też po prostu mali 'źli' (I 8). W opozycji do nich mówił o chrześcijanach, że są humiles 'pokorni, cisi' (I pr.), iusti 'sprawiedliwi' 
(I 8) czy boni 'dobrzy' (I 8). Również pogańskich bogów określał jako pysznych i butnych, mówiąc superbae animae spiritus inflatus (I pr.). Ponadto mówił, że są oni inmundi spiritus, czyli plugawymi duchami, nieczystymi moralnie (VI pr.). O samej zaś religii pogańskiej mówi, że jest ona eversio probitatis et honestatis (I 33), czyli odwróceniem prawości i uczciwości. Do tego pola należy również rzeczownik foeditas 'brzydota' (VIII 5), którym Augustyn ogólnie określa religię pogańską. Na osobne potraktowanie zasługuje natomiast takie określenie z tego pola jak impii 'bezbożni' (I pr. ' $^{6}$. W kulturze antycznej bowiem bezbożnymi byli ludzie, którzy lekceważyli powinności nie tylko względem bogów, ale także innych ludzi. Gwałcili oni zasady współżycia w danej społeczności, burząc pax deorum, czyli równowagę pomiędzy ludźmi a bogami. Za bezbożny czyn nie był karany człowiek, który się go dopuścił, ale cała jego społeczność. Augustyn, mówiąc o poganach, że byli impii, nie tylko stawiał ich w opozycji do ,pobożnych” chrześcijan, ale musiał zdawać sobie sprawę, że w rzeczywistości oskarża ich o zburzenie ładu i spokoju w Imperium Romanum. O samych chrześcijanach nie mówił, że byli pii, jednak we wstępie do księgi VII określał ogólnie religię chrześcijańską jako pietas 'pobożność'.

Zupełnie inny charakter ma pole semantyczne verba dicendi, które służy przede wszystkim do określenia pogan jako tych, którzy zarzucają coś lub uwłaczają Bogu i chrześcijanom. Poganie zatem adversus Deum murmurare non dubitant 'nie wahają się szemrać przeciwko Bogu' (I 35), mala Christo inputant 'zarzucają zło Chrystusowi' (I 1) oraz petulanter et procaciter insultant Christianis ‘bezczelnie i nieumiarkowanie uragają chrześcijanom' (I 1). Do tej grupy można również zaliczyć takie sfrazeologizowane wyrażenia jak linguas adversus Christi nomen exercere 'ostrzyć języki przeciwko imieniu Chrystusa' (I 3) czy in Christum maledictis hostilibus prosilire 'ciskać na Chrystusa złowrogie przekleństwa' (I 3).

Inne określenia, których używał Augustyn, można przyporządkować polom semantycznym związanym z metaforycznym spojrzeniem na religię pogańską i bogów pogańskich jako państwo bądź też chorobę. Zwłaszcza pole civitas było rozbudowane w dziele biskupa Hippony, co nie powinno dzi-

6 Tłumaczenie w tym artykule impius jako 'bezbożny', a tym samym pietas jako 'pobożność' jest pewnym uproszczeniem ze strony autora. W rzeczywistości znaczenie owego przymiotnika jest dużo bardziej złożone, jednakże wyjaśnienie wymaga osobnej rozprawy. 
wić, jeżeli weźmiemy pod uwagę treść pozytywnej części traktatu poświęconą przedstawieniu państwa Bożego - civitas Dei (I pr.) i ziemskiego - civitas terrena (I pr.). Chrześcijanie byli tutaj określani jako populus Dei 'lud Boży' (I pr.) i idonei cives 'sumienni obywatele' (I 1), sam Bóg chrześcijański był zaś conditor 'założycielem' (I pr.), rex ‘królem' (I pr.) i rector 'władcą (II 21) tego państwa. Ponadto był On, w przeciwieństwie do bogów pogańskich, którzy byli dei victi 'bogami zwyciężonymi' (I 3) oraz custodes, quos Roma perdidit 'opiekunami, których Rzym stracił' (I 3), invictissimus et fidelissimus custos 'niepokonanym i bardzo szczęśliwym strażnikiem' (I 10)7 . Ciekawe jest, że bogowie pogańscy byli tutaj ukazani jako istoty bierne, sami poganie zaś jako aktywne. Oni to bowiem byli inimici 'nieprzyjaciółmi' (I 1; IV 1) i alieni 'obcymi' (I 1), adversus quos defendenda est Dei civitas 'przeciwko którym trzeba bronić państwa Bożego’ (I 1).

Kolejnym polem semantycznym, którego określeń Augustyn używał do metaforycznego przedstawienia zarówno religii pogańskiej, jak i chrześcijaństwa, było pole choroby. I jemu właśnie chcę bliżej się przyjrzeć w niniejszym artykule. Pole to służyło biskupowi Hippony do skonstruowania czterech szczególnie rozbudowanych metafor (II 1; VI pr., IX 17; X 29), jednakże i przygodnie wykorzystywał słownictwo z tego pola, np. przy określaniu Chrystusa jako medicus (IV 16; V 14). Pierwsza z nich pojawiała się na początku księgi II:

Si rationi perspicuae veritatis infirmus humanae consuetudinis sensus non auderet obsistere, sed doctrinae salubri languorem suum tamquam medicinae subderet, donec divino adiutorio fide pietatis inpetrante sanaretur, non multo sermone opus esset ad convincendum quemlibet vanae opinationis errorem his, qui recte sentiunt et sensa verbis sufficientibus explicant. Nunc vero quoniam ille est maior et taetrior insipientium morbus animorum, quo inrationabiles motus suos [...] tamquam ipsam rationem veritatemque defendunt. (Aug., D.c.D., II 1)

7 Warto zwrócić uwagę na przymiotniki w stopniu najwyższym, które podkreślają wszechmoc Boga (tzw. gradus elativus). Gradus superlativus Augustyn używał również jako przydawki w stosunku do pewnych autorów chrześcijańskich, co nabierało jednak w tych użyciach zabarwienia ironicznego, np. określa Warrona jako doctissimus 'najuczeńszy' (III 4; VII 30), acutissimus 'najprzenikliwszy' (VII 9; 28), w stosunku do wiedzy i rzymskich starożytności) czy gravissimae auctoritatis 'o najwyższym autorytecie' (IV 1), ale tylko w stosunku do innych Rzymian (III 4; IV 1), którzy nie zostali natchnieni Duchem Świętym (VI 6). 
Z zacytowanego fragmentu można wyodrębnić cztery leksemy należące do pola semantycznego choroby: rzeczowniki languor, medicina i morbus, a także czasownik sano, -are. Pole to według Porziga ma charakter syntaktyczny, a słownictwo w jego obrębie możemy podzielić na dwie grupy wyrazowe - zgodnie z podstawową i wspólną dla wszystkich teorii pól myślą, że „rozumienie znaczenia słowa wiąże się z przywoływaniem innych leksemów przynależących do danej domeny semantycznej” (Tokarski 2006: 36). Zarysowują się nam one już w przytoczonym wyżej fragmencie. Mamy tam bowiem grupę określeń związanych stricte z chorobą, tzn. rzeczowniki określające choroby (wspomniane już languor, morbus, ale także aegritudo ${ }^{8}$ ) oraz przymiotniki i czasowniki wskazujące na samych chorych (aegrotus czy ei, qui aegrotant albo ei, qui morbidi sunt). Augustynowi określenia $\mathrm{z}$ tej grupy służyły do przedstawienia religii pogańskiej jako choroby, bogów pogańskich jako jej źródła, natomiast pogan jako chorych. Kolejna grupa stoi w opozycji do pierwszej i wiąże się z czynnością uzdrawiania. Mamy tu zatem określenia lekarza (medicus, curans), lekarstwa (medicina) oraz samej czynności uzdrawiania (sano, -are). Augustyn wyrazy z tej grupy wykorzystywał do budowy wizerunku Boga jako lekarza oraz Ewangelii jako lekarstwa9 .

Zacznę jednak od grupy leksemów związanych z określeniami choroby. Przyjrzę się najpierw rzeczownikom, które na język polski można przetłumaczyć po prostu jako 'choroba', a zatem bliskoznacznym morbus, languor i aegritudo. W celu wykazania różnic semantycznych między tymi jednostkami należy jednak dokonać dokładnych badań kontekstowych każdej z nich.

8 Augustyn używał również nazw hiponimicznych w stosunku do tych trzech leksemów, przede wszystkim określeń na choroby umysłowe, np. amentia, dementia, furor czy insania. Jednakże ich bliskość semantyczna ze słowami typu stultitia, które należałoby raczej umieścić w pole epistemicznym, sprawia, że należy dla nich stworzyć albo osobne pole, albo dokonać szczegółowej analizy semantycznej tych jednostek, na co w niniejszym artykule, niestety, nie ma miejsca. $Z$ tego też powodu jednostki te nie będą przedmiotem analizy.

9 Teoretycznie można wyodrębnić jeszcze jedną grupę w tym polu semantycznym, a mianowicie grupę komplementarną do grupy związanej z określeniami choroby, tj. w której znajdą się określenia zdrowych, takie jak salvo, -are, salvus czy saluber. W niniejszym artykule nie zaliczam ich jednak do tego pola semantycznego, gdyż nie są używane w metaforach przyrównujących religię pogańską do choroby. U pisarzy chrześcijańskich wyrazy te nabrały nowego znaczenia, tj. były określeniami zbawienia, zatem są zupełnie innymi jednostkami niż ich klasyczne homonimy. 
Aulus Geliusz definiował morbus następująco:

Nam „morbus” in lege ista non febriculosus neque nimium gravis, sed vitium aliquod inbecillitatis atque invalentiae demonstratur, non periculum vitae ostenditur. (Gell., XX 1, 27)

Wyraz ten mógł zatem znaczyć tyle co valetudo adversa 'nieprzyjazny stan zdrowia'. Takie znaczenie widać już u Plauta:

Quaeso advenienti morbo medicari iube:

tu certe aut larvatus aut cerritus es. (Pl., Amph., frg. 8)

czy Arnobiusza:

Quodsi possent adscribere valetudines a aegritudines et corporales diis morbos, non dubitarent eos lienososi, lippulosi atque enterocelicos dicere, eo quod ipsi et lienosi et lippi fiunt saepe et ingentium gricenearum magnitudine ponderosi. (Arnob. Nat., VII 34; ale także: Cic., Tusc., III 59; Liv., XLI 21, 11; Apul., Plat., II $\left.14^{10}\right)$

W tych fragmentach można więc wyraźnie zauważyć, że chodzi tu o 'zły stan zdrowia'. Augustyn w takim znaczeniu użył go chociażby w Confessiones:

Cumque hanc sententiam verbis quibus poterat explicasset, conticuit et ingravescente morbo exercebatur. (Aug., Conf., IX 11)

Rzeczownik ten w tym znaczeniu może zostać także doprecyzowany poprzez dodanie przymiotnika, np. Campanus u Horacego (Sat., I 5, 62), gdzie Campanus morbus oznaczało wtedy zwykłą u Kampańczyków chorobę ob-

10 Cytaty przedstawiają konteksty z różnych przestrzeni synchronicznych, by wykazać zmienność lub niezmienność danego pojęcia. Przyjęto założenie, że jeżeli dany wyraz $\mathrm{w}$ takim znaczeniu nie wystąpił w tekstach np. epoki archaicznej, a dopiero w epoce cycerońskiej (żeby posługiwać się tu konwencjonalnymi określeniami podziału diachronicznego rzymskiego antyku), to dopiero od tego okresu można mówić o tym znaczeniu. Jest to oczywiście założenie, które nie może wyjść poza rozważania hipotetyczne, ze względu na bardzo mały korpus tekstów, który zachował się do naszych czasów. Niemniej jednak o starożytności zdecydowana większość tez badawczych ma charakter tylko hipotetyczny, co nie umniejsza ich wartości poznawczej. 
jawiającą się wyrastaniem narośli na czole lub rzeczownika w apozycji, np. u Lukrecjusza, kiedy opisuje chorobę słoniowa - elephas morbus, albo w genetiwie wskazując na umiejscowienie choroby, np. morbus oculorum 'choroba oczu' (Cic., Verr., II 5, 11). Morbus z dodaną do niego przydawką oznacza wtedy konkretną chorobę dotykającą człowieka. Rzeczownik ten może jednak być również użyty w szerszym znaczeniu na określenie każdego zjawiska, które ma negatywny wpływ na organizm człowieka. Może to zatem być np. starość, jak to widzimy u Terencjusza (Phorm. 575) senectus ipsast morbus, czy niepohamowany głód:

Vis tamen illa mali postquam consumpserat omnem materiam derantque gravi nova pabula morbo, ipse suos artus lacerans divellere morsu coepit et infelix minuendo corpus alebat

(Ovid., Met., VIII 875-878; por. Aug., Conf., IX 8)

Dodatkowo morbus może nabrać znaczenia przenośnego i wtedy oznacza przede wszystkim pewne przykrości, smutki, których doznaje człowiek, albo namiętności, którym ulega ciało. Oba przykłady możemy znaleźć u Plauta. Pierwszy z nich np. w komedii Asinaria:

Arg. Salve. Phil. Salvere me iubes, quoi tu abiens offers morbum.

Arg. Mater supremam mihi tua dixit, domum ire iussit. (P1., Asin., 593-594)

Drugi zaś w Miles gloriosus:

Pyrg. Levandum morbum mulieri video. Mil. Vt tremit atque extimuit, postquam te aspexit. Pyrg. Viri quoque armati idem istuc faciunt, ne tu mirere eius mulierem. sed quid $<$ illa $>$ volt me facere?

Milph. Ad se ut eas: tecum vivere volt atque aetatem exigere.

$$
\text { (Pl., Mil., 1272-1275) }
$$

W bardzo podobnym znaczeniu rzeczownika morbus używał Augustyn w swoich Confessiones, gdzie określał tak pożądliwość, której ulegał za młodu: 
Timebam enim ne me cito exaudires et cito sanares a morbo concupiscentiae, quem malebam expleri quam exstingui. (Aug., Conf., VIII 7; por. także VI 12; VI $15 ;$ X 35)

Należy jednak zwrócić uwagę na to, że dla biskupa Hippony owa pożądliwość najprawdopodobniej nie była morbus dlatego, że „dręczyła” człowieka, tylko dlatego, że była grzechem, a więc chorobą duszy, gdyż o innych grzechach również mówi jako o morbi:

De contentione autem et dolo quid me attinet dicere, quando ista vitia non in plebe, sed in nostro numero graviora sunt? Horum autem morborum mater superbia est. (Aug., Epist., XXII 2, 7; por. także XXXII, Carm. 56)

Morbus z reguły odnosi się do istot żywych, głównie ludzi, jednak mniej więcej od epoki cycerońskiej może dotykać również rzeczy. Pierwsze takie użycie znajdujemy u Lukrecjusza w De rerum natura, gdzie wyraźnie mówi, że choroba może dotknąć świat:

Nam cum res tantis morbis tantisque periclis

temptarentur, ibi si tristior incubuisset

causa, darent late cladem magnasque ruinas. (Lucr., V 345-347; por. także: Verg., Georg., III 478; Colum., I pr., 2)

Bardzo późno natomiast morbi doświadczają rośliny, gdyż w tym kontekście używał tego rzeczownika tylko Pliniusz Starszy w Historia naturalis:

Morbis quadripedum, arborum quoque, illa medendum, efficaci ad ulcera interiora humani quoque oris. (Plin., Hist. nat., XV 33; por. także: XVI 44; XVII 226; XIX 176)

U Augustyna jednak takie użycia nie występują.

Kolejnym wyrazem, którego używa Augustyn na określenie choroby, był rzeczownik languor. Nonius opisuje je jako torpor et inertia 'brak czucia i chęci do działania' $(338,23)$ oraz defectio et dissolutio 'słabość i utrata sił' (338, 25), można zatem zdefiniować je dokładnie jako defectus virium, czyli utrata sił, pewne osłabienie. Widać to już w komedii Asinaria Plauta: 
Ubi saepe ad languorem tua duritia dederis octo validos lictores, ulmeis adfectos lentis virgis. (Pl., Asin., 574-575)

A także u Augustyna w Sermones:

Si autem ipse homo corpus suum portet, validus currit, macer languore vix ambulat. (Aug., Serm., 242, 10; por. także: Cic., De div., II 128; Ovid., Met., XI 612; Petron., 129, 4)

W tekstach z epoki augustowskiej można dostrzec powstanie drugiego znaczenia languor właśnie jako choroby, stanu osłabienia ciała. Po raz pierwszy widzimy to u Horacego:

Crescit indulgens sibi dirus hydrops

nec sitim pellit, nisi causa morbi

fugerit uenis et aquosus albo

corpore languor. (Hor., Carm., II 2, 13-16)

Podobnie używa go Augustyn w Confessiones:

Denique tam multa faciebam corpore in ipsis cunctationis aestibus, quae aliquando volunt homines et non valent, si aut ipsa membra non habeant aut ea vel conligata vinculis vel resoluta languore vel quoquo modo impedita sint. (Aug., Conf., VIII 8; por. także Colum., VI 4, 2; Cypr., Epist., 69, 12)

O ile languor odnosi się głównie do ciała, o tyle od epoki cycerońskiej można również znaleźć jego użycia w odniesieniu do ducha lub rozumu. Przykład taki widzimy w De legibus Cycerona:

Ecce autem successere huic $<\mathrm{G}>\mathrm{elli}<\mathrm{us}>$, Clodius, Asellio, nihil ad Coelium, sed potius ad antiquorum languorem et inscitiam. (Cic., De leg., I 6; por. Aug., D.c.D., XV 6)

Languor właśnie w tym znaczeniu szczególnie często używa Augustyn, zwłaszcza w odniesieniu do duszy: 
Quibus tamen philosophis, quod sine salutari nomine Christi essent, curationem languoris animae meae committere omnino recusabam. (Aug., Conf., V 14; por. także: IV 11; X 30; Trini., XIV 17, 23)

Później rzeczownik ten w ogóle stał się synonimem szaleństwa czy obłędu (por. Quint., Decl., 291; Firm., Err., XVI 5).

Nowe określenie choroby u Augustyna można znaleźć pod koniec 29. paragrafu księgi X De civitate Dei. Pisał on tam:

Ut parum sit miseris quod aegrotant, nisi se etiam in ipsa aegritudine extollant et de medicina, qua sanari poterant, erubescant ${ }^{11}$. (Aug., D.c.D., X 29)

Rzeczownik aegritudo jest derywatem od przymiotnika aeger 'chory', początkowo jednak musiał odnosić się do choroby ducha, czyli smutku albo jakiejś troski. Takie znaczenie bowiem przybiera u Plauta:

Phil. Numquid nam ad filium haec aegritudo attinet?

Nic. Admodum. Phil. Idem mihi morbus in pectorest. (Pl., Bacch., 1110-1111)

A także kilka wieków później u Apulejusza:

At iuvenis nihil etiam tunc sequius suspicatus summisso vultu rogat ultro praesentis causas aegritudinis. (Apul., Met., X 3)

U Augustyna w tym znaczeniu nie występuje, a jeżeli odnosi się do ducha, to zawsze oznacza grzeszność duszy:

Non igitur monstrum partim velle, partim nolle, sed aegritudo animi est, quia non totus adsurgit veritate consuetudine praegravatus. (Aug., Conf. VIII 9; por. także: VI 1; Epist., XXII 1, 2)

Aegritudo w znaczeniu corporis afflictio, czyli jakiejś udręki cielesnej, w tekstach występuje bardzo późno, gdyż po raz pierwszy u Pomponiusza Meli w De chorographia:

11 Oprócz aegritudo i aegroto, -are, które wskazuje na stan chorego, mamy tutaj jeszcze leksemy z grupy leczenia, a więc znane z wcześniejszego fragmentu (II 1) medicina i sano, -are. 
Quidam proximos parentes priusquam annis aut aegritudine in maciem eant velut hostias caedunt, caesorumque visceribus epulari fas et maxime pium est. (Pomp. Mela, III 64)

I od tego czasu staje się bardzo popularnym określeniem choroby, co widzimy również u biskupa Hippony:

Quamvis enim absentibus nobis, cum Romae iam essemus, corporali aegritudine correptus et in ea christianus et fidelis factus ex hac vita emigravit. (Aug. Conf., IX 3; por. także: V 9; Plin., Hist. nat., IV 89; Flor., II 17, 10; Apul., Apol., 69; Ambr., Exam., VI 6, 39).

Podsumowując rozważania na temat tych trzech bliskoznacznych rzeczowników, a więc morbus, languor i aegritudo, chciałbym teraz wyraźnie wskazać, na podstawie powyższych użyć, subtelne różnice, jakie między nimi zachodzą. Wydaje się, że morbus jest chorobą cięższą czy też poważniejszą niż aegritudo. Languor natomiast należy traktować jako zespół cech, objawów choroby, które widać u cierpiącego na nią, a więc ogólny stan chorobowy apatii, braku sił. Widać to nie tylko u przytoczonych wyżej pisarzy, ale także w zacytowanych fragmentach Augustyna. On sam jednak, chociaż używa tych rzeczowników zarówno w ich pierwszym znaczeniu, jak i przenośnych, nie stara się rozróżniać znaczeń tych wyrazów i traktuje je synonimicznie.

Z grupy leksemów omawianego pola semantycznego, które odnoszą się bezpośrednio do choroby i chorowania, Augustyn używa także wyrazów na określenie pogan jako osób dotkniętych chorobą, czyli religią pogańską. Robił to na dwa sposoby, po pierwsze, używając substantywizowanego przymiotnika aegrotus we wstępie do księgi VI, gdzie mówi o poganach jako insanabiles aegroti 'nieuleczalnie chorych', oraz po drugie, używając czasownika aegroto, -are, np. w księdze X (29), gdzie mówi o tych qui aegrotant.

Przymiotnik aegrotus, podobnie jak omówiony wyżej rzeczownik aegritudo, pochodzi od aeger. W przeciwieństwie do niego odnosi się jednak głównie do corpore infirmus, a więc chorowitości ciała. Widać to już w komedii Plauta Curculio:

Phaed. [...] Id eo fit, quia hic leno, aegrotus incubat in Aesculapi fano, is me excruciat. (P1., Cur., 61-62) 
A także Metamorphoses Apulejusza:

Nam quod habuit, dum filium curat aegrotum, consumpsit atque contrivit omne. (Apul., Met., VI 16; por. także: Cic., Tusc., III 12; Tac., Ann., XV 60)

Występuje jednak również w znaczeniu zatroskanego lub trapionego jakimś smutkiem, tylko dużo rzadziej, np. u Terencjusza:

Si. Em id te oro ut ante eamu', dum tempus datur dumque ei(u)s lubido occlusast contumeliis, priu' quam harum scelera et lacrumae confictae dolis redducunt animum aegrotum ad misericordiam, uxorem demu'. (Ter., Andr., 556-560; por. także: Cic., Tusc., III 8; Arator, I 794)

Substantywizowane aegrotus oznacza tylko chorego i po raz pierwszy również występuje u Plauta w komedii Captivi:

Heg. Multis holeribus. Erg. Curato aegrotos domi.

numquid vis? Heg. Venias temperi. Erg. Memorem mones. (Pl., Cap., 190-191; por. także: Cic., Phil., I 11; Lact., Inst., III 8, 11; Aug., Epist., XL 4, 4)

We wstępie do księgi VI De civitate Dei Augustyn wzmocnił aegrotus przydawką insanabilis. Przymiotnik ten jest złożeniem in- z sanabilis, oznaczającym coś uleczalnego. Przedrostek in- dodany do wyrazu zakłada komplementarnośćc ${ }^{12}$ tych dwóch jednostek. A zatem przymiotnik insanabilis dodany do wyrazu oznaczającego chorobę podkreśla jej nieuleczalność:

Verum ego tam furiosae consternationis oblitus remedia insanabilibus conor adhibere. (Curt., X 2, 21; por. także: Hor., Ars, 300; Lact., Inst., VII 1, 16)

Od opisanego wyżej aegrotus pochodzi kolejny interesujący nas leksem, a mianowicie aegroto, -are. Jest on bliskoznaczny np. z czasownikiem langueo, -ere i znaczy dokładnie coś przeciwnego niż sanum sum ‘jestem zdrowy'. W tym znaczeniu występuje np. u Plauta:

12 Komplementarność rozumiem tutaj za Tokarskim (1984). 
Tibi ego numquam quicquam credam, nisi si accepto pignore.

Tu vel suda vel peri algu, vel tu aegrota vel vale.

Barbarum hospitem mi in aedis nil moror. (Pl., Rud., 581-583)

A także w trzecim liście Pliniusza Młodszego:

Aegrotabat Caecina Paetus maritus eius, aegrotabat et filius, uterque mortifere, ut videbatur. (Plin., Epist., 16, 3; por. także: Cic., Cluent., 37; Hor., Epist., I 7, 4; Hier., Epist., XXII 35)

Zasadniczo odnosi się on do istot żywych, jednak, zgodnie ze znaczeniem komponentów semantycznych jego podstawy słowotwórczej, może także dotyczyć ducha. I tak u Lucyliusza odnosi się do ułomności intelektualnej:

Animo qui aegrotat, videmus corpore hunc signum dare tum doloribus confectum corpus animo obsistere (Lucil., 581),

u Cycerona zaś do pożądliwości ducha:

Quis enim dubitarit quin aegrotationes animi, qualis est avaritia, gloriae cupiditas, ex eo, quod magni aestumetur ea res ex qua animus aegrotat, oriantur? (Cic., Tusc., IV 79; por. także: Sen., Dial., IV 13, 1).

Ponadto w sposób bardziej metaforyczny może być on odniesiony do przedmiotów:

Adde quod absumunt viris pereuntque labore, adde quod alterius sub nutu degitur aetas, languent officia atque aegrotat fama vacillans. (Lucr., I 1122-1124)

Augustyn bardzo często używał czasownika aegroto, -are. Warto jednak zwrócić uwagę na to, że nie tyle w kontekście wyrażającym chorobę duszy (chociaż również; por. Aug., Conf., II7), co przede wszystkim chorobę ciała. Widać to chociażby w Confessiones:

Cum aegrotaret, quodam die defectum animae passa est et paululum subtracta a praesentibus. (Aug., Conf., IX 11; por także: V 10; VIII 3) 
Zawsze, kiedy biskup Hippony chciał powiedzieć o kimś, że chorował, to najczęściej wyrażał to właśnie za pomocą tego czasownika.

Za winnych wywołania choroby pogaństwa Augustyn uważał bóstwa pogańskie, które traktował jak demony, upadłe anioły. Pisał jednak, że i one są ogarnięte chorobą:

Hoc ut sanetur, quoniam inmortali puritati, quae in summo est, ea quae in imo sunt mortalia et inmunda conuenire non possunt, opus est.quidem mediatore; non tamen tali, qui corpus quidem habeat inmortale propinquum summis, animum autem morbidum similem infimis (quo morbo nobis inuideat potius ne sanemur, quam adiuuet ut sanemur). (Aug., D.c.D., IX 17)

Mamy tu kolejny leksem z grupy związanej z chorowaniem, a mianowicie morbidus. Przymiotnik ten znaczy tyle co morbis infectus 'zarażony chorobami', a więc jest bliskoznaczny aegrotus. Był stosunkowo rzadko używany i to raczej po srebrnym okresie języka łacińskiego. Występuje jednak już u Lukrecjusza:

Nec minimam partem ex agris maeror is in urbem confluxit, languens quem contulit agricolarum copia conveniens ex omni morbida parte. (Lucr., VI 1259-1261)

Mógł on odnosić się zarówno do ludzi, jak to widać w powyższym cytacie (por. także: Sen., Dial., VI 11, 4; Apul., Apol., 44; Aug., D.c.D., XIII 18), jak i zwierząt:

Is ait, cum sint apes morbidae propter primoris vernos pastus, qui ex floribus nucis graecae et cornus fiunt, coeliacas fieri atque urina pota reficiendas. (Varro, Re. rust., III 16, 22; por. także: Plin., Hist. Nat., VIII 96; Colum., VI 5, 1).

W odniesieniu do choroby ducha przymiotnika morbidus użył Seneka:

Sed omnia ista facile perferemus, sorbitionem, aquam calidam, et quidquid aliud intolerabile videtur delicatis et luxu fluentibus magisque animo quam corpore morbidis: tantum mortem desinamus horrere. (Sen., Epist., 78, 25) 
Pisarze pogańscy rzadko jednak używali tego przymiotnika w tym kontekście, zdecydowanie częściej robili to pisarze chrześcijańscy (por. Lucif., Athan., I 28; Aug., D.c.D., IX 17).

Opisane wyżej leksemy wyczerpują grupę pola semantycznego ,choroby" związaną z nazwami choroby i chorowaniem. Zgodnie z myślą Augustyna, zawartą w dalszej części przytoczonego wyżej fragmentu z IX księgi, bogowie pogańscy nie są w stanie wyleczyć chorego. Może to jednak uczynić Chrystus:

[...] tali, qui nobis infimis ex corporis mortalitate coaptatus inmortali spiritus iustitia, per quam non locorum distantia, sed similitudinis excellentia mansit in summis, mundandis liberandisque nobis uere diuinum praebeat adiutorium. (Aug., D.c.D., IX 17)

Przydomek medicus biskup Hippony nadał Chrystusowi jeszcze w dwóch innych miejscach swojego dzieła (IV 16; V 14). Tym rzeczownikiem rozpoczniemy analizę grupy wyrazów związanych z leczeniem, do których należy także curans, będące podobnie jak medicus określeniem osoby leczącej, oraz niejednokrotnie już przywoływane sano, -are oraz medicina.

Medicus w opinii antycznych pisarzy był to ten, qui usum ac studium et disciplinam habet medendi (Rufin., Orig. in Rom., V 5) albo per quem sanitas recuperatur (Aug., Serm., 278, 3, 2). Z reguły tym rzeczownikiem określano zatem nie wszystkich, którzy leczyli (chociaż i tak bywał używany, ale rzadko; por. Mart., 11, 71; Paul. Nol., Carm., XX 214), ale tych, którzy mieli do tego specjalistyczne przygotowanie. Słowo to zatem było określeniem profesji, w związku z czym nie dokonywały się w nim większe zmiany semantyczne, a ewentualna potencja semantyczna tego słowa ulegała zmianie wraz ze zmianą charakteru profesji. Widać to przykładowo przy zestawieniu fragmentu komedii Plauta z Rerum rusticarum Warrona. U tego pierwszego bowiem ewidentnie medicus był człowiekiem wolnym, co było charakterystyczne dla Grecji okresu klasycznego:

Tynd. Optumum atque aequissumum oras optumusque hominum es homo. sed is privatam servitutem servit illi an publicam?

Heg. Privatam medici Menarchi. Tynd. Pol is quidem huius est cliens. (Pl., Capt., 333-335) 
Za czasów Warrona natomiast patrycjuszy było stać na posiadanie wykwalifikowanego niewolnika, który był medykiem:

Itaque in hoc genus coloni potius anniversarios habent vicinos, quibus imperent, medicos, fullones, fabros, quam in villa suos habeant, quorum non numquam unius artificis mors tollit fundi fructum ${ }^{13}$. (Varro, Re. Rust., I 16, 4)

Dopiero w literaturze chrześcijańskiej doszło do większej zmiany znaczeniowej, kiedy to słowo stało się jednym z przydomków Chrystusa, co widać również u Augustyna w przytoczonych na początku akapitu przykładach (por. także: Tert., Patient., 15; Orig., In lev., VIII 1; Aug., Conf., II 7).

We wstępie do VI księgi De civitate Dei możemy także spotkać się z określeniem lekarza jako curans. Jest to oczywiście substantywizowane participium praesentis activi, które jest synonimem wyrazu curator. Po raz pierwszy w funkcji rzeczownika zostało użyte u Tertuliana w Ad nationes:

Platonici quidem curantem rerum et arbitrum et iudicem, Epicurei otiosum et inexercitum, et, ut ita dixerim, neminem; positum uero extra mundum Stoici, intra mundum Platonici. (Tert., Ad nat., II 2)

Dalsze badanie znaczenia curans oprę na podstawie analizy semantycznej curator. Oznacza on dokładnie osobę, qui alicuius rei vel personae curam agit. W takim ogólnym znaczeniu możemy spotkać ten rzeczownik np. u Warrona:

Inter duas ostium sit, qua gallinarius, curator earum, ire possit. In caveis crebrae perticae traiectae sint, ut omnes sustinere possint gallinas. (Varro, Re. Rust., III 9, 7; por. także Arnob., Nat., IV 9)

Zdecydowanie częściej jednak ma znaczenie bardziej szczegółowe, np. dla określenia jakiejś funkcji publicznej, przykładowo obowiązków edylów:

13 Oczywiście w Rzymie również ludzie wolni zajmowali się medycyną, co można zobaczyć chociażby u samego Augustyna: „Erat eo tempore vir sagax, medicinae artis peritissimus atque in ea nobilissimus, qui proconsul manu sua coronam illam agonisticam imposuerat non sano capiti meo, sed non ut medicus" (Aug., Conf., IV 3). 
Suntoque aediles curatores urbis annonae ludorumque sollemnium, ollisque ad honoris amplioris gradum is primus ascensus esto. (Cic., De leg., III 7)

Bądź też funkcji prywatnej:

Erat ei Numida quidam negotiorum curator, fidus acceptusque et omnium consiliorum nisi novissimi particeps. (Sall., Iug., 71, 3)

W węższym znaczeniu curator może oznaczać również tego, który zajmuje się ars medicina, czyli medicus. Takie użycie znajdujemy dopiero jednak w tekstach chrześcijańskich:

Sed qui concipiunt timorem Dei, et per liberum arbitrium subdunt se sanandos optimo medico, et sicut bono curatori, ita et misericordi creatori, per humilitatem confessionis et poenitentiae sanantur. (Aud., Contra fel., II 9; por. także Ennod., Opusc., V 13)

Medicus czy curans to jest ten, qui sanat (Aug., De c.D., IX 17), zatem dla oddania czynności leczenia Augustyn używał sano, -are. Występowanie tego czasownika w tekstach antycznych można zauważyć począwszy od epoki cycerońskiej i od początku oznaczało ono 'leczyć, uzdrawiać, zarówno w odniesieniu do zdrowia fizycznego:

Inveteratio autem, ut in corporibus, aegrius depellitur quam perturbatio, citiusque repentinus oculorum tumor sanatur quam diuturna lippitudo depellitur (Cic., Tusc., IV 81; por. także: Ovid., Met., XIV 23; Plin., Nat. Hist., XVI 250),

jak i psychicznego:

Medico tria milia iugerum; quid, si te sanasset? (Cic., Phil., II 101; por. także: Sen., Epist., 78, 6; Plin., Nat. Hist., XIX 45).

Równocześnie jednak można zaobserwować przenośne użycie sano, -are. Po pierwsze, może ono przybrać węższe znaczenie, określające przywrócenie komuś zdrowego rozsądku:

Restant actionis, cuius alterum est praecipiendi genus quod ad rationem officii pertinet, ut quemadmodum colendi sint parentes, alterum autem ad sedan- 
dos animos et oratione sanandos, ut in consolandis maeroribus, ut in iracundia comprimenda aut in timore tollendo aut in cupiditate minuenda. (Cic., Part., 67, por. także Ov., Rem. Am., 814)

Po drugie, może nabrać szerszego znaczenia, określając sytuację bądź rzeczy, które są naprawiane, „uzdrawiane”:

Consules deinde T. Geganius P. Minucius facti. Eo anno cum et foris quieta omnia a bello essent et domi sanata discordia, aliud multo grauius malum ciuitatem inuasit, caritas primum annonae ex incultis per secessionem plebis agris, fames deinde, qualis clausis solet. (Liv., II 34,1; por. także: Cic., Sul., 28; Apul., Fl., 6)

U Augustyna czasownik sano, -are występuje np. w Confessiones w odniesieniu do zdrowia cielesnego:

Et tamen in salute corporis non dicimus: 'sine vulneretur amplius: nondum enim sanatus est' (Aug., Conf., I 11),

nie używa go natomiast w odniesieniu do ludzkiej psychiki. Można jednak zauważyć pewne rozszerzenie znaczenia tego słowa u biskupa Hippony na sferę duchowa. Człowiek bowiem może zostać wyleczony z różnego rodzaju przypadłości duchowych, np. smutku czy bólu:

Quo vulnere si feriretur cor matris, numquam sanaretur. (Aug., Conf., V 9; por. także IX 12)

albo grzechów, takich jak pożądliwość cielesna (Aug., Conf., II 7; por. także: VI 4; VI 6).

Czasownik sano, -are, jak to zostało powiedziane wyżej, jest określeniem czynności leczenia przez medyka, Augustyn częściej używał go jednak w stronie biernej, by nie tyle zaakcentować aktywność Boga, ale podkreślić możliwość i sposób uleczenia „chorych” już pogan (por. wyżej cytowane fragmenty IX 17 i X 29). Uzdrowienie może dokonać się tylko dzięki medicina 'lekarstwu', którym jest doctrina salubris, czyli nauka Chrystusa (Aug., De c.D., II 1; X 29). Rzeczownik medicina ma dwa różne podstawowe znaczenia. W pierwszym z nich medicina to ars, czyli dyscyplina naukowa (por. Aug., Conf., IV 3), w drugim zaś znaczy tyle co remedium, auxilium lub sub- 
didium. Użycie tego rzeczownika jako leku widać na przykład w zachowanym fragmencie tragedii Akcjusza:

Se uenenis sterilem esse illius opera et medicina autumans

Quaeue ut Graio tibi congenerat gentum aut generum adfinitas? (Acc., 579; por. Plin., Hist. Nat., XVII 240)

W tekstach antycznych medicina mogła być jednak również lekiem na różnego rodzaju pożądliwości ducha lub wypaczenia obyczajów:

Principiis obsta; sero medicina paratur,

Cum mala per longas convaluere moras (Ovid., Rem. Amor., 91-92; por. Plaut., Cist., 74; Apul., Plat., II 18)

albo środkiem na usunięcie jakiegoś zła:

Et tu oblivisci iubes, quod contra naturam est, qui, <quod $>$ a natura datum est, auxilium extorqueas inveterati doloris? Est enim tarda illa quidem medicina, sed tamen magna, quam adfert longinquitas et dies (Cic., Tusc., III 35; por. Ov., Trist., IV 10, 118; Tac., Ann. I 49, 2),

skąd już bliska droga do chrześcijańskiego rozumienia tego rzeczownika.

Zaprezentowane wyżej leksemy pola semantycznego „choroby” u Augustyna występowały w bardzo różnych kontekstach. W jego pismach możemy znaleźć ich użycia zgodnie z ich pierwotnym znaczeniem, jak również metaforyczne. Tych drugich w tekstach biskupa Hippony jest zdecydowanie więcej. Często bowiem mówi o grzechu jako chorobie duszy (Aug., Conf., VI 15) i Bogu jako lekarzu, który może ją uzdrowić (Aug., Conf., IV 3). Wydaje się jednak, że jest to po prostu podyktowane szeroko rozumianym dyskursem chrześcijańskim. Dopiero w De civitate Dei mamy do czynienia z bardziej świadomym wykorzystaniem wyrazów z pola semantycznego „choroby” do budowy metafor podporządkowanych konstruowaniu opozycji „my - chrześcijanie” i ,oni - poganie”. Augustyn bowiem nie ogranicza się tutaj do prostego wskazania chorych (poganie) i lekarza (Bóg), ale pokazuje również źródło choroby (bogowie pogańscy), nazywa tę chorobę (religia pogańska) i mówi, jak ją wyleczyć (Ewangelia). O ile w późniejszych dziełach biskup 
Hippony również używa wyrażeń z tego pola semantycznego, o tyle nigdzie już nie robi tego w sposób tak złożony.

$\mathrm{Na}$ zakończenie warto jednak zaznaczyć, że tego typu metafory nie były obce również literaturze pogańskiej. Wystarczy chociażby tutaj sięgnąć do pierwszej mowy In Catilinam Cycerona:

Ut saepe homines aegri morbo gravi cum aestu febrique iactantur, si aquam gelidam biberunt, primo relevari videntur, deinde multo gravius vehementiusque adflictantur, sic hic morbus, qui est in re publica, relevatus istius poena vehementius reliquis vivis ingravescet. (Cic., Cat., I 31)

\section{Źródla}

Acc.: L. Accius, 1980, I frammenti delle tragedie, ed. V. d'Anto, Lecce: Milella.

Apul. Met.: L. Apuleius Madaurensis, 1955, Metamorphoseon libri XI, [in:] Apulei Platonici Madaurensis opera quae supersunt, Vol. 1, ed. R. Helm, Lipsiae: B. G. Teubner.

Arnob. Nat:: Arnobius of Sicca, 1953, Adversus nationes libri VII, ed. C. Marchesi, Aug. Taurinorum: Io. Bapt. Paraviae et Sociorum.

Aug. Conf:: Aurelius Augustinus Hipponensis, 1934, Confessionum libri tredecim, ed. M. Skutella, Lipsiae: B. G. Teubneri.

Aug. Contra fel.: Aurelius Augustinus Hipponensis, 1892, Contra Felicem, ed. I. Zycha, Vindobonae: F. Tempsky.

Aug. D.c.D.: Aurelius Augustinus Hipponensis, 1981, De civitate Dei libri XXII, ed. B. Dombart et A. Kalb, Stutgardiae: B. G. Teubneri.

Aug. Epist.: Aurelius Augustinus Hipponensis, 2004, Epistulae I-LV, ed. Kl. D. Daur, Turnholti: Brepols.

Cic. Cat.: M. Tullius Cicero, 1897, Ciceros catilinarische Reden, ed. Fr. Richter und A. Eberhard, Leipzig: B. G. Teubner.

Cic. De leg.: M. Tullius Cicero, 1950, De legibus, ed. K. Ziegler, Heidelberg: F. H. Kerle.

Cic. Phil.: M. Tullius Cicero, 1982, In M. Antonium orationes Philippicae XIV, ed. P. Fedeli, Leipzig: B. G. Teubner.

Cic. Tusc.: M. Tullius Cicero, 1918, Tusculanae disputationes, ed. M. Pohlenz, Lipsiae: B. G. Teubneri.

Cic. Verr.: M. Tullius Cicero, 2004, In C. Verrem actionis secundae liber quartus, ed. G. Baldo, Firenze: F. Le Monnier. 
Curt.: Q. Curtius, 1946, History of Alexander, vol. 2, ed. J. C. Rolfe, London: Heinemann.

Gell.: Aulus Gellius, 1903, Noctium Atticarum libri XX, vol. 2, ed. C. Hosius, Lipsiae: B. G. Teubneri.

Hor. Carm.: Q. Horatius Flaccus, 2000, Ody i epody, oprac. O. Jurewicz, Warszawa: Wydawnictwo Naukowe PWN.

Liv.: T. Livius Patavinus, 1919, History of Rome, vol. 1, ed. B. O. Foster, London: Heinemann.

Lucil.: C. Lucilius, 1961, Fragmenta, [in:] Remains of old Latin. 3: Lucilius; The twelve tables, London, Cambridge: Harvard University Press.

Lucr.: T. Lucretius Carus, De rerum natura libri sex, ed. O. Gigon, Turici: Orell Füssli.

Ovid. Met.: P. Ovidius Naso, 1985, Metamorphoses, ed. W. S. Anderson, Leipzig: BSB B. G. Teubner Verl.-Ges.

Ovid. Rem. Amor.: P. Ovidius Naso, 1969, Heilmittel gegen die Liebe; Die Pflege des weiblichen Gesichtes, ed. F. W. Lenz, Berlin: Akademie-Verlag.

Pl. Amph.: T. Maccius Plautus, 1850, Amphitruo, [in:] Comoediae, ed. Alfredi Fleckeiseni, Lipsiae: B. G. Teubner.

Pl. Asin.: T. Maccius Plautus, 1850, Asinaria, [in:] Comoediae, ed. Alfredi Fleckeiseni, Lipsiae: B. G. Teubner.

Pl. Bacch.: T. Maccius Plautus, 1850, Bacchilides, [in:] Comoediae, ed. Alfredi Fleckeiseni, Lipsiae: B. G. Teubner.

Pl. Capt.: T. Maccius Plautus, 1850, Captivi, [in:] Comoediae, ed. Alfredi Fleckeiseni, Lipsiae: B. G. Teubner.

Pl. Cur.: T. Maccius Plautus, 1850, Curculio, [in:] Comoediae, ed. Alfredi Fleckeiseni, Lipsiae: B. G. Teubner.

Pl. Mil.: T. Maccius Plautus, 1850, Miles gloriosus, [in:] Comoediae, ed. Alfredi Fleckeiseni, Lipsiae: B. G. Teubner.

Pl. Rud.: T. Maccius Plautus, 1850, Rudens, [in:] Comoediae, ed. Alfredi Fleckeiseni, Lipsiae: B. G. Teubner.

Plin. Epist:: C. Plinius Caecilius Secundus, 1923, Epistularum libri novem, Epistularum ad Traianum liber, Panegyricus, ed. R. C. Kukula, Lipsiae: B. G. Teubneri.

Plin. Hist. nat.: C. Plinius Secundus, 1942-1950, Natural history, vol. 2-5, ed. H. Rackham, London: Heinemann.

Pomp. Mela: Pomponius Mela, 1994, Kreuzfahrt durchdie alte Welt, ed. K. Brodersen, Darmstadt: Wissenschaftliche Buchgesellschaft.

Sall. Iug.: C. Sallustius Crispus, 1921, War with Catiline. War with Jugurtha. Selections from the Histories. Doubtful Works, ed. J. C. Rolfe, London: Heinemann.

Sen. Epist.: L. Annaeus Seneca, 1898, Ad Lucilium epistularum moralium quae supersunt, ed. O. Hense, Lipsiae: B. G. Teubner. 
Ter. Andr.: P. Terentius Afer, 1916, Andria, [in:] Comoediae, ed. A. Fleckeisen, Lipsiae: B. G. Teubneri.

Ter. Phorm.: P. Terentius Afer, 1916, Phormio, [in:] Comoediae, ed. A. Fleckeisen, Lipsiae: B. G. Teubneri.

Tert. Ad nat:: Tertullian, 1953, Ad nationes, [in:] Tertvlliani opera: pars I: opera catholica adversus Marcionem, pars I, Tvrnholti: Typographi Brepols Editores Pontificii.

Varro, Re. rust.: M. Terentius Varro, 1889, Rervm rvsticarvm libri tres, ed. H. Keil, Lipsiae: B. G. Teubneri.

\section{Bibliografia}

Brown P., 1993, Augustyn z Hippony, tłum. W. Radwański, Warszawa: Państwowy Instytut Wydawniczy.

Buttler D., 1967, Koncepcje pola znaczeniowego, Przeglad Humanistyczny, z. 2, s. 41-59.

ECKmann A., 1987, Dialog świętego Augustyna ze światem pogańskim w świetle jego korespondencji, Lublin: Redakcja Wydawnictw KUL.

Kornatowski W., 1977, Wstęp, w: Święty Augustyn, O państwie Bożym przeciw poganom ksiag XXII, Warszawa: PAX.

Pisarek W., 1967, Pojęcie pola wyrazowego i jego użyteczność w badaniach stylistycznych, Pamiętnik Literacki LVIII, z. 1-2, s. 493-516.

TOKARSKi R., 1984, Struktura pola znaczeniowego, Warszawa: PWN.

TokARski R., 2006, Pola znaczeniowe i ramy interpretacyjne - dwa spojrzenia na język, LingVaria I, z. 1, s. 35-46.

\section{The semantic field of disease in De Civitate Dei of Augustine of Hippo}

( su m mary)

In this paper I try to analyze the lexemes belonging to the semantic field of disease in the apologetic treatise "De Civitate Dei" of Augustine of Hippo. This treaty was written in order to deal with pagan religion and to present the concept of the two states: the divine and the earthly. To accomplish this aim, Augustine first builds the opposition "we - the Christians" and "they - the pagans", and employs vocabulary from six different semantic fields: epistemic (veritas, errores, imperiti, falsi), quantitative (unus, multi, turba), moral (humiles, superbi, eversio probitatis, impii, impietas), verba dicendi (adversus Deum mururare), civitas (custos, rector, idonei 
cives, inimici), and disease (morbus, medicus, medicina). In this article I briefly present the first five fields, and in more detail the semantic field of disease, which, like the field civitas, was applied by the Bishop of Hippo in a metaphorical presentation of the pagan religion. 